\title{
Za ili protiv života na selu? Stavovi visokoobrazovanih mladih ljudi o životu u hrvatskim ruralnim područjima
}

\author{
Tihana Kuzmić \\ Sveučilište u Zagrebu, Filozofski fakultet, Odsjek za sociologiju, Hrvatska \\ e-mail:kuz.tih@gmail.com
}

\section{Bruno šimac}

Sveučilište u Zagrebu, Filozofski fakultet, Odsjek za sociologiju, Hrvatska e-mail:bsimac@ffzg.hr

\author{
Tijana Trako Poljak \\ Sveučilište u Zagrebu, Filozofski fakultet, Odsjek za sociologiju, Hrvatskaa \\ e-mail: ttrako@ffzg.hr
}

SAŽETAK Odlazak mladih predstavlja jedan od ključnih problema za opstanak hrvatskih ruralnih područja, kako u demografskom tako i posljedično u ekonomskom, socijalnom, kulturnom, političkom i svakom drugom smislu. Smanjenje udjela mladih u ruralnom stanovništvu očituje se u senilizaciji ruralnih područja, deagrarizaciji, odnosno sveukupnoj deruralizaciji i kontinuiranom propadanju tih područja kao mjesta življenja i rada. S obzirom na to da mlado stanovništvo uglavnom odlazi zbog daljnjeg obrazovanja ili zaposlenja, prilike za što ima naročito malo za one s višim obrazovanjem, cilj je ovog rada istražiti koji su to čimbenici privlačenja i odbijanja iz perspektive hrvatskog mladog visokoobrazovanog stanovništva da se vrate ili dođu živjeti u ruralna područja.

U ovom će radu biti prikazani rezultati kvantitativnog empirijskog istraživanja provedenog metodom internetske ankete 2020. godine na prigodnom uzorku od $N=582$ studenata šest fakulteta Sveučilišta u Zagrebu, čime su obuhvaćena sva ključna znanstvena i umjetnička područja. Studenti su odgovarali na pitanja o tome kako percipiraju prednosti i nedostatke života u ruralnim područjima, žele li se nakon završenog studija vratiti ili preseliti u njih te o razlozima zašto. Izjasnili su se i o tome koji su im elementi infrastrukturne opremljenosti važni da bi se odlučili živjeti u ruralnim područjima, budući da se to pokazalo važnim čimbenikom u ranijim istraživanjima. Rezultati su korelirani i s osnovnim sociodemografskim obilježjima ispitanika.

Rezultati pokazuju da se $40 \%$ studenata želi vratiti/preseliti u ruralna područja, i to preko polovice $(55 \%)$ onih koji su porijeklom iz ruralnih područja, a značajno manje onih iz urba- 
nih područja, koji preferiraju ostanak u gradu. Za povećanje privlačnosti ruralnih područja visokoobrazovani mladi ključnim smatraju poboljšanje komunalne i prometne infrastrukture, ali i mogućnost zaposlenja u struci, prije svega omogućavanjem bolje prometne povezanosti $s$ gradovima u kojima planiraju raditi. Vezano za rad u poljoprivredi, smatraju da bi im novčani poticaji, posebice urbanim mladima koji nemaju obiteljsko zemljište ili postojeću infrastrukturu, olakšali početak bavljenja poljoprivredom.

Ključne riječi: ruralni egzodus, deagrarizacija, visokoobrazovano mlado stanovništvo, hrvatska ruralna područja, ruralni razvoj.

\section{Uvod ${ }^{1}$}

Hrvatska se ruralna područja danas suočavaju s ozbiljnim demografskim problemima, čije je ključno obilježje senilizacija, odnosno odlazak i nevraćanje mladih stanovnika. O odlasku mladih govore i podaci o prosječnoj starosti stanovništva, koja je u posljednjih pedesetak godina s 30,7 godina (1953.) porasla na 41,7 godina (2011.) (Državni zavod za statistiku, 2011.). Drugi je ozbiljan problem deagrarizacija budući da su oni koji ostaju u ruralnim naseljima pretežito starije životne dobi, te ih se većina više ne bavi poljoprivredom kao djelatnošću (Šundalić, 2010.; Štambuk, 2014.), pa zajedno sa stanovništvom ruralnih područja odumire i poljoprivreda kao zanimanje.

Glavni razlozi trajnog napuštanja hrvatskih ruralnih područja među radno aktivnim i reproduktivnim stanovništvom su ekonomski, uključujući potragu za boljim zaposlenjem i boljim uvjetima rada izvan poljoprivrednog zanimanja (Grgić i sur., 2010.:600; Šundalić, 2006.:141; Stipić, 2018.:20). Loša infrastrukturna opremljenost (Župančić, 2005.; Svirčić Gotovac, 2006.; Štambuk i Mišetić, 2002.) također je ključan razlog zašto mladi napuštaju ta područja kao mjesta stanovanja (Žutinić i Bokan, 2008.:151; Šundalić, 2006.:141; Babić i Lajić, 2001.:79; Grgić i sur., 2010.:600; Pupak, 2020.:40) te odlaze u gradove koji su infrastrukturno opremljeniji.

Mladi predstavljaju ključne aktere za spas ruralnih područja od odumiranja, pri čemu su posebno zanimljivi visokoobrazovani mladi ljudi, koji nerijetko nakon privremenog odlaska iz ruralnih područja u veće gradove radi nastavka obrazovanja tamo trajno ostaju. Također, visokoobrazovani mladi iz gradova rijetko se odlučuju za preseljenje te život i rad u ruralnim područjima. Međutim, upravo su visokoobrazovani mladi ljudi važni nositelji ruralnog razvoja. U ovom radu fokusirat ćemo se stoga na visokoobrazovano mlado ruralno i urbano stanovništvo te istražiti privlačne i potisne čimbenike

\footnotetext{
${ }^{1}$ Rad je nastao na temelju diplomskog rada Tihane Kuzmić „Za ili protiv života na selu? Stavovi visokoobrazovanih mladih ljudi o životu na hrvatskim selima“", pod mentorstvom doc. dr. sc. Tijane Trako Poljak, obranjenog 2020. godine na Odsjeku za sociologiju Filozofskog fakulteta u Zagrebu.
} 
ostanka u gradu odnosno povratka ili preseljenja u ruralna područja nakon završetka studija.

U prvom dijelu rada, osim ciljeva i svrhe rada, kontekstualizirat ćemo ključne razloge zbog kojih hrvatska ruralna područja ostaju bez mladog stanovništva (što dovodi do ruralnog egzodusa / deruralizacije i deagrarizacije). Drugi dio rada donosi rezultate provedenog empirijskog istraživanja metodom internetske ankete na prigodnom uzorku studentske populacije šest fakulteta Sveučilišta u Zagrebu $(\mathrm{N}=582)$. Fakulteti na kojima je istraživanje provedeno pripadaju pet različitih znanstveno-umjetničkih područja: Prirodoslovno-matematički fakultet, Fakultet strojarstva i brodogradnje, Agronomski fakultet, Šumarski fakultet, Filozofski fakultet i Akademija likovnih umjetnosti. Studenti su odgovarali na pitanja o svojoj percepciji prednosti i nedostataka života u hrvatskim ruralnim i urbanim područjima, kao i o željama vezanim uz ostanak u gradu ili vraćanje/preseljenje u ruralna naselja. Osim toga pitani su i o infrastrukturnim elementima, koji su se pokazali važnim potisnim čimbenikom u ranijim istraživanjima hrvatskih ruralnih mladih. Odgovori su dodatno korelirani s ispitanim sociodemografskim obilježjima ispitanika (spol, fakultet, godina studija, religioznost, politička opredijeljenost, veličina mjesta najduljeg prebivanja) kako bi se utvrdilo postoje li statistički značajne razlike s obzirom na želju za životom u ruralnim područjima. Kako je ruralna sociologija kao područje istraživanja posljednjih godina izgubila na svojoj privlačnosti te su, uz vrijedne iznimke, ruralni mladi kao tema posebno zapostavljeni, kako još Petak upozorava 2002. godine (Petak, 2002.:45), nadamo se da će ovo istraživanje pomoći doprinijeti boljem razumijevanju motivacije, a time i prostora za djelovanje na visokoobrazovanu mladu populaciju, čiji su povratak/preseljenje ključni za revitalizaciju i razvoj ruralnih područja.

\section{Teorijski okvir}

\subsection{Deruralizacija i deagrarizacija}

Pojavom industrijalizacije i modernizacije nakon Drugog svjetskog rata u Hrvatskoj je započeo i proces propadanja ruralnih područja (za detaljniji opis, vidjeti: Petak, Puljiz i Štambuk, 2002.; Župančić, 2000.). Proces industrijalizacije doveo je do degradacije primarnog sektora djelatnosti (poljoprivrede) te smanjenja važnosti ljudskog rada, koji se sada prebacuje na proizvodnju pomoću strojeva. Industrijalizacijom se glavnina proizvodnje premješta u gradove i dolazi do deagrarizacije (napuštanja poljoprivrede kao djelatnosti i prelaska stanovništva u nepoljoprivredne djelatnosti). Premještanjem proizvodnje u gradove dolazi i do premještanja stanovništva iz ruralnih u urbana područja. Time je „radikalno izmijenjena ali i osuvremenjena socijalna struktura sela. S druge strane, nepovoljan položaj seljačke poljoprivrede i ideološke predrasude prema seljaštvu i privatnom vlasništvu uopće, kao i neprimjerena razvojna politika prema selu, doveli su do stagnacije i izrazitog zaostajanja mnogih seoskih regija" (Župančić, 
2000.:39). Kao posljedica javlja se „snažna depopulacija, a ponegdje i prava socijalna i demografska depresija u znatnom dijelu seoskog prostora" (Župančić, 2000.:39). Drugim riječima, priljevom stanovništva u gradove dolazi do ruralnog egzodusa, koji se odnosi na masovno napuštanje ruralnih područja kao mjesta stanovanja. Transformativni modernizacijski procesi te opća deruralizacija koja se očituje u odlasku stanovništva iz ruralnih područja dovode i do nestajanja tradicionalnih vrijednosti i obrazaca seljačkog načina života (Cifrić, 2018.:13-14).

U procesu ruralnog egzodusa u najvećoj mjeri sudjeluju mladi koji obrazovanje i priliku za djelomičnim ili potpunim zaposlenjem izvan ruralnih područja koriste kao svojevrsnu kartu za privremeni bijeg iz ruralnih naselja, koji nerijetko postaje i trajan. Tim procesom iz ruralnih područja odlazi velik dio radno sposobnog i reproduktivnog stanovništva, što bitno utječe na demografsku sliku ruralnih područja i u smislu smanjenog broja novorođenih. Zbog nemogućnosti biološke reprodukcije brojna naselja ostaju bez ijednog stanovnika. Prema Popisima stanovništva iz 2001. i 2011. godine vidljivo je da se broj naselja bez stanovnika sa 105 (2001.) povećao na čak 150 (2011.) (DZS, 2001.; 2011.). Odlaskom mlađeg stanovništva, osim bioloških, pogoršavaju se i „obrazovne strukture, tako da u depopulacijskim naseljima ostaje malobrojno stanovništvo koje postaje ograničavajući činilac daljnjeg razvoja" (Nejašmić, 1990.:47). Odlazak stanovništva iz ruralnih naselja ima negativan učinak i na gradove u koje to stanovništvo dolazi. Naime, „u prostornom je razmještaju stanovništva došlo do ‘preskakanja malih i srednjih centralnih naselja, a do «uskakanja u velike gradove. To je negativno odjeknulo u iskorištavanju prirodnih resursa i proizvodnih potencijala čitavih regija" (Nejašmić, 1990.:47). Samim time ruralni egzodus negativno utječe ne samo na ruralna naselja već i na društveno-gospodarsku sliku cijele zemlje.

Deagrarizacija, isto kao i ruralni egzodus, ima velik utjecaj na negativne promjene u hrvatskim ruralnim područjima. Važno je naglasiti da deagrarizacija nužno ne mora značiti urbanizaciju, odnosno „deagrarizacija i urbanizacija međusobno se odnose kao koncentrični krugovi: deagrarizacija je veći, a urbanizacija manji krug" (Puljiz, 2002.:4). Puljiz proces deagrarizacije dijeli u dva vala. Prvi val, ili „direktni transfer“ javlja se početkom šezdesetih godina i odnosi se na poljoprivrednike koji su zamijenili zanimanje bez prethodne pripreme, poslove nalaze u tvornicama, gradilištima i sl., a eventualne kvalifikacije stječu za vrijeme radnog odnosa (Puljiz, 2002.:375). Drugi val naziva ,indirektnim transferom“, odnosi se na poljoprivrednike koji mijenjaju zanimanje putem školovanja te se pojavljuje uvođenjem obveznog školovanja (Puljiz, 2002.:376). Drugi val ili tip deagrarizacije dominantan je i danas.

S obzirom na deagrarizaciju, u strategijama regionalnog i ruralnog razvoja više je nego ikada naglasak na motivaciji mladih da odaberu poljoprivredu kao zanimanje (npr. mladi se poljoprivrednici u Programu ruralnog razvoja Republike Hrvatske smatraju ključnim resursom za moderan i konkurentan poljoprivredni sektor; Ministarstvo 
poljoprivrede, 2018.:125). Istovremeno, malu potražnju za poljoprivrednim zanimanjima u srednjim školama pokazuje činjenica da u Hrvatskoj imamo svega 11 srednjih škola koje su vezane uz poljoprivredu, od kojih su tri šumarske ili drvodjeljske (Eusmjeravanje, 2020.). No, kada pogledamo ustanove visokog obrazovanja, postoji 69 poljoprivrednih smjerova na 11 sveučilišta i veleučilišta diljem Hrvatske (MOZVAG - preglednik studijskih programa, 2020.). Iznimno je važno omogućiti mladima dostupno i kvalitetno obrazovanje za poljoprivrednu djelatnost, ali i kvalitetne uvjete života u ruralnim područjima i bavljenja tim zanimanjem.

\subsection{Mladi u ruralnim područjima - za ili protiv?}

Postojeća istraživanja koja ukazuju na motivaciju za migraciju ruralnih mladih bogata su, te ćemo se ovdje osloniti samo na nekoliko studija iz europskih zemalja koje nam mogu pomoći kontekstualizirati nalaze postojećih istraživanja u Hrvatskoj. Ta istraživanja prije svega ukazuju na ekonomske razloge kao ključne potisne čimbenike za ruralne mlade. U istraživanju razloga za migraciju ruralne mladeži iz Rumunjske Horváth (2008.) tako pokazuje da ruralni mladi migriraju u potrazi za boljim plaćama nego što ih mogu dobiti u vlastitoj zemlji, kao i boljom sigurnosti posla. Do sličnih rezultata dolazi i Stockdale (2006.) u istraživanju u Škotskoj, a Thissen i sur. (2010.) ukazuju na važnost obrazovanja i ekonomskih čimbenika kao povoda za odlazak ruralnih mladih u Belgiji i Nizozemskoj. Možemo reći da je ekonomska motivacija povezana i s odgovorima studenata agronomije u Rusiji, čija je želja za povratkom povezana sa željom da se bave poljoprivredom kao zanimanjem, ali i prethodnim posjedovanjem obiteljskog zemljišta i percepcijom o tome koliko će im biti jednostavno uspostaviti vlastito poduzeće (Bednaříková, Bavorova i Ponkina, 2016.). Međutim, neka istraživanja ukazuju i na važnost neekonomskih čimbenika kao što su zadovoljstvo životom (Bednař́ḱková, Bavorova i Ponkina, 2016.) te osjećaj pripadnosti mjestu (Thiseen i sur., 2010.).

Neka domaća istraživanja pokazuju da se mladi u gotovo jednakom postotku dijele na one koji žele živjeti u ruralnim i one koji žele živjeti u urbanim naseljima (Šundalić, 2010.). Seferagić (2002.:22) smatra da je prva grupa mladih iznimno važna jer predstavljaju svojevrsne pokretače razvoja: „Oni u selo unose suvremene tipove odnosa, osnovane na: slobodi izbora, težnji napredovanju i učenju novoga, na nuklearnoj porodici, modernoj proizvodnji, obučavanju suseljana...". Međutim, iako ruralna područja posjeduju brojne prednosti življenja kao što su čist i svježi zrak, nezagađena priroda, niži životni troškovi, domaća prehrana i sl. koje se pojavljuju kroz istraživanja o motivaciji ruralnih mladih da ostanu ili odu iz ruralnih područja, ta ista istraživanja ukazuju na nekoliko ključnih potisnih čimbenika, među kojima su najčešći problemi oko zaposlenja u i izvan poljoprivrede te infrastrukturna neopremljenost. 
Kao i u ranije navedenim europskim istraživanjima, i u Hrvatskoj ruralni mladi imaju problem oko zaposlenja. Tako Grgić i sur. (2010.:600) pokazuju da su glavni razlozi trajnog napuštanja hrvatskih ruralnih područja među radno aktivnim stanovništvom ekonomske prirode, te uključuju potragu za boljim zaposlenjem i uvjetima rada. Kod problema vezanih za zaposlenje u nepoljoprivrednim zanimanjima javlja se problem pronalaska zaposlenja u svojoj profesiji izvan poljoprivrede, otežana uspostava vlastitih poslovnih prilika i otežan pristup edukaciji (Žutinić i sur., 2010.:152; Žutinić i Bokan, 2008.:150; Šundalić, 2006.:141; Stipić, 2018.:20, 35). Vezano za zaposlenje u poljoprivrednim zanimanjima mladi upozoravaju na loše uvjete rada, te su ta nekada dominantna zanimanja u ruralnim područjima postala neprofitabilna, a time i sve manje privlačna, kako ističe Šundalić (2006.:141). Za mlade je poljoprivrednike važno i posjedovanje vlastitog zemljišnog posjeda i popratne infrastrukture za obavljanje poljoprivredne djelatnosti, što nemaju mnogi koji ne nasljeđuju obiteljske posjede (Pupak, 2020.:31).

Kao još jedan ključni problem u hrvatskim ruralnim područjima mladi najčešće navode lošu infrastrukturnu opremljenost (Žutinić i Bokan, 2008.:151; Šundalić, 2006.:141; Babić i Lajić, 2001.:79; Grgić i sur., 2010.:600; Pupak, 2020::40). Iako su se kuće u ruralnim područjima, kada govorimo o infrastrukturi i osnovnim instalacijama, gotovo u potpunosti izjednačile s gradskim kućama (Hodžić, 2006.), ostala infrastruktura ruralnih naselja uvelike zaostaje. Istraživanje koje je 2005. godine proveo Župančić na 154 naselja i 2.220 ispitanika pokazalo je da je infrastrukturna i institucionalna opremljenost vrlo loša (Župančić, 2005.). Najveći broj ruralnih naselja ima lošu komunalnu infrastrukturu, brojna nemaju kanalizaciju te stanovnici moraju sami zbrinjavati otpadne vode (Župančić, 2005.:638-640). Prometna infrastruktura nije na odgovarajućoj razini: autobusnu vezu ima oko polovina istraženih ruralnih područja, dok su željeznički i brodski promet dostupni samo manjem broju naselja (Župančić, 2005.:650-651). Prema Župančićevu istraživanju (2005.:640-641), od zdravstvenih ustanova $45 \%$ naselja ima ambulantu, no domovi zdravlja, ljekarne i stomatološke ambulante nalaze se u lokalnim središtima ili češće u obližnjim gradovima. Broj je osnovnih škola zadovoljavajući, no velik broj školaraca ima malu dostupnost srednjih škola, pa su primorani putovati u županijska središta (Župančić, 2005.:643645). Kada govorimo o kulturnim ustanovama, njih gotovo nema, dok više od tri četvrtine ruralnih naselja nema financijske službe (Župančić, 2005.:645-647). Važno je da ljudi iz ruralnih područja imaju mogućnost relativno brzo stići do obližnjeg urbanog naselja, gdje se nalaze sve ustanove koje kod njih nedostaju, što ukazuje na važnost mreže naselja (Župančić, 2005.:632-634; Svirčić Gotovac, 2006.:121; vidjeti i: Pupak, 2020.:40). No, loša prometna povezanost otežava dnevne migracije stanovnika ruralnih područja, pa ih i to prisiljava da promijene mjesto stanovanja kako bi im putovanje do infrastrukturno bolje opremljenih naselja kao i posla bilo brže i kraće. Istraživanja su pokazala da ona naselja koja su ostala bez stanovnika najčešće imaju ili manjak prirodnih resursa ili su prometno izolirana, te je u njima bilo gotovo nemoguće stvoriti suvremene životne uvjete (Nejašmić, 1990.). Dakle, nedovoljno razvijena infrastruktura svakako je u nas, uz socioekonomske razloge vezane za zaposlenje, važan 
razlog zbog kojeg mladi ljudi koji odlaze u veće gradove, zbog primjerice obrazovanja, tamo odlučuju i ostati.

\subsection{Visokoobrazovani ruralni mladi}

Što se tiče obrazovanja ruralnih mladih, visokoobrazovanih je ljudi u ruralnim područjima općenito iznimno malo. To potvrđuje i Popis stanovništva iz 2011. godine, iz kojeg je vidljivo da samo $8,4 \%$ žena i 7,9\% muškaraca sa završenom višom školom stanuje van gradskih naselja (DZS, 2011.). Istraživanje Šuljok iz 2016. godine o socijalnom porijeklu visokoobrazovanih mladih u Hrvatskoj pokazuje da iako se broj visokoobrazovanih ljudi s ruralnim korijenima skromno povećao (Šuljok, 2006.:297), i dalje je vrlo nizak broj visokoobrazovanih koji su podrijetlom iz ruralnih područja (Šuljok, 2006.:304). Za to postoje dva glavna razloga: neodlučivanje ruralnih mladih na visoko obrazovanje te nepovratak nakon odlaska na studij.

Dio razloga neodlučivanja ruralnih mladih na visoko obrazovanje može biti u tome što na profesionalne aspiracije mladih u velikoj mjeri utječe socijalno podrijetlo (obiteljski prihodi, obrazovanje i zanimanje roditelja te mjesto prebivališta) (Šuljok, 2006.:304305). Tako velik postotak visokoobrazovanih mladih ljudi najčešće ima visokoobrazovane roditelje i podrijetlom su iz grada (Šuljok, 2006.:304). Osim toga, veliku ulogu ima i dostupnost obrazovnih i kulturnih institucija (Šuljok, 2006.:294), pa mladi iz grada imaju dostupnije primjerice knjižnice, čitaonice i škole, dok su mladima u ruralnim područjima takvi sadržaji teže dostupni, što dovodi do razlika u obrazovnim šansama. Naravno, razlozi mogu biti i u financijskoj dostupnosti daljnjeg obrazovanja, kao i potrebi za posebnim visokim obrazovanjem, ovisno o odabiru profesije.

Međutim, činjenica je i da se dio ruralnih mladih koji odlaze na visoko obrazovanje u gradove nakon završetka studija ne vraća u ruralna područja. To je poseban problem jer na taj način potencijalni nositelji razvoja odlaze iz ruralnih područja, a dolazi do centralizacije visokoobrazovanog kadra u gradovima. Zbog toga smo se u ovom radu fokusirali na populaciju visokoobrazovanih mladih te smo htjeli utvrditi koji su razlozi koje mladi ruralnog porijekla daju za ostanak u gradu ili povratak u ruralna područja nakon studija odnosno koje mladi urbanog porijekla daju za ostanak u gradu ili preseljenje u ruralna područja.

\subsection{Ciljevi i hipoteze rada}

Glavni je cilj ovog rada utvrditi koji su razlozi zbog kojih se dio visokoobrazovane mlade populacije vraća/preseljava u ruralna područja, a dio ne vraća / ne preseljava nakon završenog studija. U istraživanju ispitujemo i pogled mladih na život u ruralnim područjima u usporedbi sa životom u gradovima. Dio istraživanja odnosi se na infrastrukturne elemente kao važne pokazatelje kvalitete življenja i u literaturi dokaza- 
ne čimbenike koji utječu na odluku o povratku/preseljenju mladih u hrvatska ruralna područja.

Na temelju predstavljenih istraživanja kao i onih koja su pokazala da žene za razliku od muškaraca u većoj mjeri preferiraju ostanak u ruralnim područjima (Stipić, 2018.), da se u sve većoj mjeri smanjuje osjećaj pripadnosti obiteljskoj lozi i obitelji (Cifrić, 2013.), koji još lakše nestaje ako se privremeno boravi van ruralnog naselja, da se visokoobrazovani pojedinci koji pripadaju biotehničkoj znanstvenoj grani češće odlučuju na povratak u ruralna područja (Šuljok, 2006.) te da među ruralnim stanovništvom dominiraju religiozniji i desno politički orijentirani (Hodžić, 2006.), postavili smo dvije glavne hipoteze ovog rada:

H1. Studenti koji su najveći dio života proveli u gradu značajno će više percipirati nedostatke života u ruralnim područjima i htjet će ostati živjeti u gradu nakon završetka studija, dok će oni koji su najveći dio života proveli u ruralnim područjima značajno više percipirati prednosti života u ruralnim područjima i htjet će se u njih vratiti nakon završetka studija.

H2. Studentice, studenti prve godine studija, studenti Agronomskog i Šumarskog fakulteta, religiozniji studenti i politički desno orijentirani studenti značajno će više percipirati prednosti života u ruralnim područjima i htjet će se vratiti u njih, u odnosu na studente, studente zadnje (pete) godine studija, studente ostalih fakulteta, nereligiozne i politički lijevo orijentirane.

\section{Metodologija}

\subsection{Anketni upitnik}

Anketni se upitnik sastojao od pet dijelova. Prvi, drugi, treći i peti dio samostalno su konstruirani za potrebe ovog istraživanja. U prvom dijelu nalazila su se pitanja vezana uz sociodemografska obilježja ispitanika: spol, godina studija, fakultet koji studenti pohađaju, veličina mjesta u kojem su proveli najveći dio života te religijska i politička orijentacija. U drugom dijelu nalazila su se pitanja vezana uz postojanje povezanosti ispitanika s ruralnim područjem općenito (postojanje uže ili šire obitelji koja živi na selu, učestalost boravka na selu, razlog boravka na selu) te pitanja vezana uz preferiranje života u ruralnim ili urbanim područjima. U trećem dijelu navedeni su brojni infrastrukturni elementi kao objektivni pokazatelji kvalitete života u smislu infrastrukturne opremljenosti i od studenata se tražilo da na ljestvici od pet stupnjeva iskažu u kojoj su mjeri za njih ti elementi važni u odluci o življenju u ruralnim područjima. Četvrti dio odnosio se na tvrdnje o životu na hrvatskim ruralnim u odnosu na urbana područja, odnosno ističu se dva seta tvrdnji: prvi vezan uz prednosti života u ruralnim 
područjima i drugi vezan uz nedostatke života na njima. ${ }^{2} \mathrm{U}$ tom dijelu zatraženo je od ispitanika da na ljestvici od 1 do 5 iskažu slaganje s navedenim tvrdnjama. Posljednji, peti dio, koji nije uključen u ovaj rad, odnosio se na tvrdnje vezane uz odlazak iz $\mathrm{Hr}$ vatske nakon studija.

\subsection{Uzorak i provedba istraživanja}

Istraživanje je provedeno na prigodnom uzorku studentske populacije prve i zadnje (pete) godine šest fakulteta Sveučilišta u Zagrebu. Fakulteti na kojima je istraživanje provedeno su: Agronomski fakultet, Akademija likovnih umjetnosti, Fakultet strojarstva i brodogradnje, Filozofski fakultet, Prirodoslovno-matematički fakultet i Šumarski fakultet. Odabirom tih šest fakulteta obuhvaćeno je svih šest znanstvenih i umjetničkih područja: biotehničko, umjetničko, tehničko, društveno, prirodoslovno i humanističko područje.

Prije provedbe procesa prikupljanja podataka dobivena je dopusnica Povjerenstva Odsjeka za sociologiju za prosudbu etičnosti istraživanja Filozofskog fakulteta Sveučilišta Zagrebu (11. svibnja 2020; 17-2019/20). Iako je istraživanje prvotno osmišljeno kao anketni upitnik koji će se provoditi uživo na fakultetima, zbog pandemije bolesti COVID-19 bili smo primorani istraživanje provesti putem interneta pomoću alata Google Forms. Prikupljanje podataka provedeno je od 15. svibnja do 15. srpnja 2020. godine. Poziv na sudjelovanje u istraživanju s poveznicom na pristup anketnom upitniku distribuiran je putem društvene mreže Facebook u grupe koje okupljaju studente različitih fakulteta Sveučilišta u Zagrebu te je objavljivan na službenim stranicama navedenih fakulteta, kao i preko pojedinih profesora studenata prvih i petih godina odabranih fakulteta. U navedenom razdoblju prikupljena su 582 ispravno ispunjena anketna upitnika.

Struktura uzorka bila je sljedeća: 29\% bili su ispitanici muškog spola, a $71 \%$ ispitanice ženskog spola; $38 \%$ studenti prve godine studija, a $62 \%$ pete godine studija. Što se tiče fakulteta koji pohađaju, 14\% su studenti Agronomskog fakulteta, 3\% Akademije likovnih umjetnosti, 15\% Fakulteta strojarstva i brodogradnje, 40\% Filozofskog fakulteta, 19\% Prirodoslovno-matematičkog fakulteta i 9\% Šumarskog fakulteta. Dakle, unatoč prigodnom uzorkovanju putem društvenih mreža, uspjeli smo uzorkom obuhvatiti studente i studentice različitih razina studija i fakulteta. No, valja naglasiti da preko tri četvrtine uzorka čine studentice, što je čest problem internetskih istraživanja, kao i da preko polovice ispitanih pohađa petu godinu studija te da preko $1 / 3$ ispitani-

2 Tvrdnje u ovom dijelu anketnog upitnika preuzete su iz istraživanja Žutinić i sur. pod nazivom „Percepcija kvalitete življenja i namjere o odlasku iz ruralnih sredina" provedenog 2006. i 2007. godine (Žutinić i sur., 2010.). Za potrebe svoga istraživanja u ovom smo dijelu dodali jednu tvrdnju „Mogućnost za zapošljavanje visokoobrazovanih ljudi u mojoj struci na selu su nepostojeće". 
ka studira na Filozofskom fakultetu, što je sve uzeto u obzir pri provođenju statističke obrade i analize prikupljenih podataka. Što se tiče ostalih sociodemografskih obilježja ispitanika, veličine naselja podijelili smo u četiri grupe: sela (do 2.000 stanovnika), lokalna središta (od 2.001 do 10.000 stanovnika), regionalna središta (od 10.001 do 100.000 stanovnika) i veliki gradovi (više od 100.000 stanovnika). Odabrali smo taj način klasifikacije budući da trenutna klasifikacija naselja, koja ih dijeli na gradska i ostala naselja (DZS, 2011.), nije bila idealna za upotrebu u ovom istraživanju. Svjesni smo da je u određenju tipa naselja važno uzeti i niz drugih čimbenika, no smatrali smo tu kategorizaciju po broju stanovnika dovoljnom za ovo istraživanje. Zbog toga smo definirali selo kao naselje koje ima do 2.000 stanovnika, a u analizi rezultata tu kategoriju uspoređujemo s naseljima između 2.001 i 10.000 stanovnika, koje smatramo mješovitim naseljima, i naseljima $s$ više od 10.001 stanovnika, koje smo podijelili na regionalna središta i velike gradove. Tako je $1 / 3$ studenata $(34,4 \%)$ najveći dio svog života provela na selu (naselju do 2.000 stanovnika), gotovo 1/4 (22,7\%) u mješovitim naseljima te nešto manje od polovice $(43 \%)$ u gradskim naseljima. Što se tiče religioznosti ispitanika, većina ispitanika (45\%) nije ili uopće nije religiozna, dok se njih 33\% izjasnilo kao religiozno ili izrazito religiozno, dok 22\% studenata nije moglo procijeniti vlastitu religioznost. Nadalje, gotovo polovica ispitanika (46\%) nije htjela odgovoriti na pitanje o političkoj orijentaciji, što upućuje na rezultate prijašnjih istraživanja koja su pokazala sve veću apolitičnost kod mladih (Ilišin, 2003.). Od onih koji su ipak dali odgovor na to pitanje njih 24\% izjasnilo se kao lijevo orijentirano, 18\% podržava politički centar, a $11 \%$ je desno orijentirano.

Statistička obrada podataka provedena je pomoću statističkog programa IBM SPSS Statistics 25. Provedene statističke analize uključivale su provođenje neparametrijskih testova povezanosti - hi-kvadrat testova, kao i parametrijskih testova - t-test za nezavisne uzorke i analiza varijance (ANOVA). Osim toga korištena je i komponentna faktorska analiza, kojom smo ispitali dimenzionalnost dviju konstruiranih skala prednosti i nedostataka života u ruralnim područjima.

\section{Rezultati i diskusija}

\subsection{Iskustvo života u ruralnim područjima}

U analizi rezultata fokusirani smo na distinkciju studenata koji su veći dio života proveli u ruralnim naseljima (do 2.000 stanovnika) od studenata ostalih naselja (mješovita naselja od 2.000 do 10.000 stanovnika te gradovi s više od 10.000 stanovnika).

Iako je manji dio ispitanika podrijetlom iz ruralnih područja, gotovo svi ispitanici (85\%) imaju užu ili širu obitelj koja živi u ruralnim područjima, pa smatramo da su upoznati s uvjetima života u njima. Njih 30\% u ruralnom području boravi u prosjeku svaki dan, a najviše oni koji su većinu života tamo i proveli (55\%). Pretpostavljamo 
da ti studenti žive u ruralnim naseljima koja su relativno blizu grada Zagreba u kojem studiraju pa svakodnevno putuju na fakultet. Osim toga, zanimljiv je podatak da više od $25 \%$ ispitanika u ruralnim područjima boravi manje od tri puta godišnje, a to su najvećim dijelom studenti koji su većinu života proveli u gradu koji ima više od 100.001 stanovnika. Osim dijela studenata koji žive u ruralnim područjima, kao najčešće razloge boravka u njima studenti navode posjećivanje obitelji i rodbine koja tamo živi, boravak u vikendici koju njihova obitelj posjeduje te odlazak u ruralna naselja kako bi posjetili prijatelje.

\subsection{Za ili protiv života na selu?}

Nešto više studenata koji su sudjelovali u istraživanju ipak preferira život u gradu (53\%) u odnosu na život u ruralnim područjima (47\%). No, 40\% studenata trenutno ima želju za povratkom/preseljenjem u ruralna područja nakon završenog studija, što je veći postotak u usporedbi sa Šundalićevim istraživanjem iz 2010. godine, u kojem je samo $24 \%$ studenata izjavilo da nakon završetka studija želi živjeti u ruralnim područjima (Šundalić, 2010.). Do takve razlike u nalazima dvaju istraživanja moguće je da je došlo zbog samog uzorka istraživanja, u koji je uključena gotovo $1 / 3$ studenata koja svaki dan boravi u ruralnom područjima, odnosno živi u okolici grada Zagreba. Ta skupina studenata u budućnosti će vrlo lako moći koristiti privilegije koje nudi veliki grad, ponajprije tu mislimo na lakše zaposlenje, a istodobno će imati mogućnost svakodnevno se vratiti mirnijem ruralnom životu. Uzroci mogu biti i u pandemiji bolesti COVID-19, koja je trajala za vrijeme našeg istraživanja i tijekom koje se u medijima i javnosti mnogo češće govorilo o prednostima života u ruralnim područjima i bavljenja poljoprivredom.

S obzirom na razlike u trenutnoj želji za životom u ruralnim područjima nakon završetka studija prema sociodemografskim obilježjima studenata: iako smo očekivali da će žene biti sklonije životu u ruralnim područjima od muškaraca, odnosno da će se u većem postotku željeti vratiti ili odseliti u ruralna područja, rezultati nam pokazuju da čak 50\% muškaraca, a samo 36\% žena u našem uzorku želi tamo živjeti. Iznos hikvadrat testa statistički je značajan, odnosno postoji statistički značajna povezanost varijable želje za povratak/preseljenje u ruralna područja te varijable spola ispitanika $(\chi 2=11,161 ; \mathrm{p}<0,01)$. Na temelju kontingencijske tablice moguće je zaključiti kako su muškarci skloniji povratku/preseljenju u ruralna područja od žena, dok su žene sklonije ostanku u gradu ili nisu razmišljale o povratku/preseljenju u ruralna područja nakon završenog studija.

Također, suprotno onome što smo pretpostavili, studenti prve godine studija trenutno su skloniji ostanku u gradu, odnosno trenutno se ne žele vratiti/preseliti u ruralna područja (35\% želi se vratiti nakon završetka studija, a 39\% ne želi), dok su studenti pete godine studija skloniji povratku/preseljenju u ruralna područja ( $43 \%$ želi se vrati- 
ti nakon završetka studija, a 39\% ne želi). Iznos hi-kvadrat testa statistički je značajan, odnosno postoji statistički značajna povezanost varijable želje za povratak/preseljenje $\mathrm{u}$ ruralna područja te varijable godine studija koju ispitanik pohađa $(\chi 2=7,504 ; \mathrm{p}<$ 0,05). Na temelju kontingencijske tablice moguće je zaključiti kako su studenti pete godine studija skloniji povratku/preseljenju u ruralna područja, dok su studenti prve godine studija skloniji nerazmišljanju o povratku/preseljenju. Iako smo, vođeni nalazom Cifrića (2013.), koji tvrdi da se u sve većoj mjeri smanjuje osjećaj pripadnosti obiteljskoj lozi i obitelji što se duže boravi van ruralnog naselja, pretpostavili da će studenti pete godine studija biti skloniji ostanku u gradu u odnosu na studente prve godine studija, naši rezultati to ne potvrđuju. Smatramo kako je do razlike u nalazima ovih dvaju istraživanja došlo zbog toga što studenti prve godine studija u puno većoj mjeri ne razmišljaju o povratku/preseljenju nakon završenog studija (gotovo $10 \%$ više studenata prve godine studija nije razmišljalo o povratku/preseljenju u ruralna područja nakon završenog studija u odnosu na studente pete godine studija). Moguće je da u pozadini tog nalaza stoji to da su studenti prve godine studija tek nedavno ušli u sustav visokog obrazovanja i prerano im je donositi odluke o tome što ih čeka nakon završetka studija, pogotovo uspoređujući ih sa studentima koji su pri kraju visokog obrazovanja i ubrzo moraju donijeti važne životne odluke o profesionalnoj karijeri.

Nadalje, kada pogledamo postotke prema fakultetu koji studeni pohađaju, moguće je vidjeti da studenti Agronomskog i Šumarskog fakulteta u većoj mjeri teže životu u ruralnim područjima. No, gotovo polovica (48\%) studenata Fakulteta strojarstva i brodogradnje također je iskazala želju za životom u ruralnim područjima. Kod studenata Prirodoslovno-matematičkog fakulteta postoji blaga prevaga onih koji ne žele živjeti u ruralnim područjima, dok je kod studenata Filozofskog fakulteta ta razlika izraženija, pa 54\% studenata tog fakulteta ne želi živjeti u ruralnim područjima. Studenti Akademije likovnih umjetnosti gotovo su u jednakom broju raspodijeljeni u one koji žele, ne žele i one koji nisu razmišljali o odlasku/preseljenju. Iznos hi-kvadrat testa statistički je značajan, odnosno postoji statistički značajna povezanost varijable želje za povratak/preseljenje u ruralna područja te varijable fakulteta koji ispitanik pohađa $(\chi 2=65,622 ; p<0,01)$. Na temelju kontingencijske tablice moguće je zaključiti kako su studenti Agronomskog i Šumarskog fakulteta najviše skloni povratku/preseljenju u ruralna područja, dok su studenti Filozofskog fakulteta najmanje skloni povratku/preseljenju u ruralna područja. Rezultati našeg istraživanja u skladu su sa Šuljok (2006.) u tome da studenti bio(tehničkih) znanosti iskazuju veću želju za životom na ruralnim područjima. Pretpostavljamo da je jedan od glavnih razloga to što oni lakše pronalaze posao u ruralnim sredinama nego studenti društvenih, humanističkih i umjetničkih znanstvenih područja s obzirom na samu prirodu zanimanja.

U skladu s našim pretpostavkama, pokazalo se da religiozniji ispitanici te oni koji ne mogu procijeniti vlastitu religioznost u većem postotku žele živjeti u ruralnim područjima nakon završetka studija. Oko polovice onih ispitanika koji se smatraju izrazito religioznima i onih koji se nisu svrstali ni u religiozne ni u nereligiozne trenutno ima želju nakon studija vratiti se / preseliti u ruralna područja. Iznos hi-kvadrat testa stati- 
stički je značajan, odnosno postoji statistički značajna povezanost varijable želje za povratak/preseljenje u ruralna područja te varijable religioznosti ispitanika $(\chi 2=39,224$; $\mathrm{p}<0,01)$. Na temelju kontingencijske tablice moguće je zaključiti kako su religiozniji studenti i oni koji ne mogu procijeniti vlastitu religioznost skloniji povratku/preseljenju, dok su nereligiozni studenti skloniji ostanku u gradu.

Nadalje, većina studenata (59\%) koji su se izjasnili kao desno politički orijentirani želi živjeti u ruralnim područjima, dok većina (55\%) onih koji su se izjasnili kao lijevo politički orijentirani nema želju za životom u ruralnim područjima. Oni koji podržavaju politički centar u gotovo su jednakom postotku podijeljeni. Iznos hi-kvadrat testa statistički je značajan, odnosno postoji statistički značajna povezanost varijable želje za povratak/preseljenje u ruralna područja te varijable političke opredijeljenost ispitanika $(\chi 2=31,147 ; \mathrm{p}<0,01)$. Na temelju kontingencijske tablice moguće je zaključiti kako su studenti desne političke orijentacije najskloniji povratku/preseljenju u ruralna područja nakon završenog studija, dok su studenti lijeve političke orijentacije skloniji ostanku u gradu. Studenti koji zauzimaju političku orijentaciju centra podijeljeni su u svojoj želji za povratak/preseljenje u ruralna područja i ostanak u urbanim.

Završni nalaz u sklopu ove analize taj je da se preko polovice studenata (55\%) koji su porijeklom iz ruralnih područja želi vratiti u njih. U ruralnim područjima želi živjeti i polovica onih koji su život proveli u naseljima od 2.001 do 10.000 stanovnika. S druge strane, preko polovice onih koji su većinu života proveli u naseljima s više od 10.001 stanovnika ne želi živjeti u ruralnim područjima nakon završetka studija. Iznos hi-kvadrat testa statistički je značajan, odnosno postoji statistički značajna povezanost varijable želje za povratak/preseljenje u ruralna područja te varijable veličine naselja u kojem su studenti proveli najveći dio života $(\chi 2=64,018 ; \mathrm{p}<0,01)$. Na temelju kontingencijske tablice moguće je zaključiti kako su studenti iz naselja do 2.000 stanovnika te studenti iz naselja između 2.001 i 10.000 stanovnika skloniji povratku/ preseljenju, dok su studenti iz naselja između 10.001 i 100.000 stanovnika te studenti iz naselja s više od 100.000 skloniji ostanku u gradu.

\subsection{Infrastrukturna opremljenost}

Gotovo 2/3 studenata odlučilo bi se na život u ruralnim područjima ako bi se ona modernizirala, a 14\% studenata iz uzorka ni nakon obnove infrastrukture ne bi željelo živjeti u ruralnim područjima. Takav postotak ukazuje na to da problem loše, a u nekim mjestima nepostojeće, infrastrukturne opremljenosti hrvatskih ruralnih naselja još uvijek nije razriješen te da je infrastrukturna opremljenost u velikoj mjeri povezana sa željom za povratak ili preseljenje u ruralna područja mladih visokoobrazovanih ljudi.

Studentima koji razmišljaju o povratku/preseljenju $(\mathrm{N}=233)$ ponudili smo da iskažu u kolikoj su im mjeri određeni infrastrukturni aspekti važni za donošenje odluke o 
potencijalnom životu u ruralnim područjima. ${ }^{3}$ Ukupno 218 studenata ispravno je ispunilo taj dio upitnika, i to 103 ispitanika podrijetlom iz ruralnih područja i 115 ispitanika iz mješovitih, odnosno manjih i većih gradskih naselja.

\section{Tablica 1.}

Potreba studenata koji žele živjeti u ruralnim područjima za infrastrukturnim elementima prema mjestu u kojem su proveli najveći dio života $(\mathrm{N}=218$; \%)

\begin{tabular}{|c|c|c|c|c|c|c|}
\hline & \multicolumn{3}{|c|}{$\begin{array}{l}\text { Ruralno naselje }(\mathrm{N}=103) \\
\qquad \%\end{array}$} & \multicolumn{3}{|c|}{$\begin{array}{c}\text { Mješovito i gradsko } \\
\text { naselje }(\mathrm{N}=115) \\
\%\end{array}$} \\
\hline & $1+2$ & 3 & $4+5$ & $1+2$ & 3 & $4+5$ \\
\hline Struja & 10,7 & 4,9 & 84,5 & 1,7 & 3,5 & 94,8 \\
\hline Vodovod & 11,7 & 8,7 & 79,6 & 5,2 & 7,8 & 87,0 \\
\hline Širokopojasni internet & 11,7 & 17,5 & 70,9 & 7,8 & 16,5 & 75,7 \\
\hline Odvoz smeća & 12,6 & 17,5 & 69,9 & 7,0 & 15,7 & 77,4 \\
\hline Trgovina mješovitom robom & 16,5 & 14,6 & 68,9 & 7,8 & 15,7 & 76,5 \\
\hline Kanalizacija & 13,6 & 18,4 & 68,0 & 12,2 & 18,3 & 69,6 \\
\hline Osnovna škola & 17,5 & 15,5 & 67,0 & 12,2 & 13,9 & 73,9 \\
\hline Dobra cestovna povezanost s gradom & 12,6 & 20,4 & 67,0 & 11,3 & 19,1 & 69,6 \\
\hline Blizina obitelji/rodbine & 23,3 & 21,4 & 55,3 & 29,6 & 27,0 & 43,5 \\
\hline Ambulanta & 17,5 & 29,1 & 53,4 & 9,6 & 14,8 & 75,7 \\
\hline Novčana potpora za mlade poljoprivrednike & 29,1 & 17,5 & 53,4 & 37,4 & 22,6 & 40,0 \\
\hline Ljekarna & 20,4 & 27,2 & 52,4 & 12,2 & 22,6 & 65,2 \\
\hline Vrtić & 23,3 & 25,2 & 51,5 & 26,1 & 20,0 & 53,9 \\
\hline Blizina grada & 23,3 & 25,2 & 51,5 & 22,6 & 26,1 & 51,3 \\
\hline Dobar odnos sa susjedima & 21,4 & 31,1 & 47,6 & 14,8 & 28,7 & 56,5 \\
\hline Plin & 28,2 & 25,2 & 46,6 & 27,0 & 20,9 & 52,2 \\
\hline Pekara & 27,2 & 26,2 & 46,6 & 18,3 & 24,3 & 57,4 \\
\hline Javni promet (autobus, željeznica...) & 27,2 & 29,1 & 43,7 & 24,3 & 28,7 & 47,0 \\
\hline Kafić & 38,8 & 20,4 & 40,8 & 39,1 & 20,9 & 40,0 \\
\hline Stomatološka ordinacija & 25,2 & 36,9 & 37,9 & 18,3 & 32,2 & 49,6 \\
\hline Veterinarska stanica & 33,0 & 29,1 & 37,9 & 23,5 & 33,9 & 42,6 \\
\hline Pošta & 34,0 & 32,0 & 34,0 & 26,1 & 27,8 & 46,1 \\
\hline Radno mjesto u mjestu stanovanja & 43,7 & 23,3 & 33,0 & 26,1 & 40,9 & 33,0 \\
\hline Park & 43,7 & 24,3 & 32,0 & 36,5 & 29,6 & 33,9 \\
\hline Banka & 41,7 & 31,1 & 27,2 & 37,4 & 27,8 & 34,8 \\
\hline Kulturne usluge i događanja & 45,6 & 32,0 & 22,3 & 38,3 & 36,5 & 25,2 \\
\hline Novčana naknada za preseljenje u ruralno područje & 56,3 & 26,2 & 17,5 & 50,4 & 32,2 & 17,4 \\
\hline
\end{tabular}

3 Za lakšu interpretaciju rezultata varijable smo rekodirali iz skale od 5 u skalu od 3 stupnja ( 1 - „Uopće nije važno, svejedno bih se odlučila na život na selu“ $+2-$ „Nije važno, svejedno bih se odlučila na život na selu“; 3 - „Nije ni važno ni nevažno za moju odluku“; 4 - „Važno mi je, bez toga se nikad ne bih odlučio/la na život na selu“ + 5 - „Iznimno mi je važno, bez toga se nikad ne bih odlučio/la na život na selu“). 
Rezultati (tablica 1) su pokazali da su osnovni elementi komunalne infrastrukture, kao što su struja, vodovod, širokopojasni internet, odvoz smeća i kanalizacija, iznimno važni za studente koji razmišljaju o odlasku iz ruralnih područja ili povratku/preseljenju u njih. Od uslužnih djelatnosti studentima je najvažnija trgovina mješovitom robom. Nadalje, i obrazovne su institucije važne za studente, pa preko $2 / 3$ ispitanika smatra da je osnovna škola važna ili iznimno važna. Za više od $2 / 3$ studenata važna je dobra cestovna povezanost $s$ gradom. Osim infrastrukturnih potreba, pokazalo se da studenti smatraju važnim i emocionalnu potporu, odnosno važno im je da stanuju u blizini obitelji i rodbine. Kod zdravstvenih ustanova studentima je najvažnije da ruralno područje u kojem bi potencijalno stanovali ima ambulantu i ljekarnu. Studenti su iskazali da im je u većem postotku važna novčana potpora za mlade poljoprivrednike u odnosu na novčanu naknadu za preseljenje, a takva novčana potpora za mlade poljoprivrednike važnija je za studente koji su veći dio života proveli u ruralnim područjima (i vjerojatno očekuju da bi se djelomično ili puno radno vrijeme bavili tim zanimanjem). Istovremeno, i studenti koji su većinu života proveli u ruralnim područjima i oni koji su ga proveli u gradovima u gotovo podjednakom postotku (51\%) smatraju važnom blizinu grada. Financijske službe kao što su banka i pošta studentima nisu izrazito važne, a ono što posebno iznenađuje izrazito je nizak postotak studenata koji smatraju važnim kulturne usluge i događanja kao što su kazalište, kino, knjižnica i sl. Ovaj rad, kao i prijašnje istraživanje koje se bavilo infrastrukturom ruralnih naselja (Župančić, 2005.), pokazao je važnost prometne infrastrukture i dobre cestovne povezanosti s gradom. Dobra povezanost $s$ gradom utječe na smanjenje potrebe stanovnika ruralnih naselja za financijskim službama, zdravstvenim uslugama, kafićima te kulturnim uslugama i događanjima u samom ruralnom naselju. Iz istih razloga studenti ne smatraju važnim da im je radno mjesto u mjestu stanovanja. Pokazalo se da studenti ne žele ruralna područja infrastrukturno izjednačiti s urbanima, pa ne zahtijevaju određene sadržaje u ruralnim područjima.

Studente smo također zamolili da u obliku otvorenog odgovora napišu ako postoji još nešto što smatraju važnim za život u ruralnim područjima. Neki od elemenata koji su važni za pojedine studente su i velik prostor oko kuće / izoliranost od susjeda, sportski tereni te organizirana društvena događanja koja bi povezala sumještane. Ono što je dio ispitanika napomenuo je da se navedeni sadržaji ne moraju nužno nalaziti u naselju u kojem bi stanovali, ali je bitno da postoje u blizini, odnosno najbližem gradu.

\subsection{Prednosti i nedostaci života na selu}

Od tvrdnji koje su sačinjavale ovaj dio upitnika konstruirali smo dvije skale: prva se skala sastoji od 14 tvrdnji koje se odnose na prednosti života u ruralnim područjima u odnosu na život u gradu, pa smo je stoga i nazvali „Prednosti života na selu“, dok se druga sastoji od 12 tvrdnji koje se odnose na nedostatke života u ruralnim područjima u odnosu na život u gradu, pa smo je nazvali „Nedostatci života na selu“. Veći rezultat 
na skali „Prednosti života na selu“ označava viši stupanj percipiranja prednosti koje donosi život u ruralnim područjima. Iako je metoda glavnih komponenata dala četiri komponente koje su zajedno tumačile 64,9\% ukupne varijance instrumenta, skala zadovoljava Carminesove i Zellerove (1979.) kriterije jednodimenzionalnosti, pa ju zato kao takvu i tretiramo u daljnjim analizama. Pouzdanost skale izražena Cronbachovim koeficijentom interne konzistentnosti je visoka $(\alpha=0,879)$. $S$ druge strane, veći rezultat na skali „Nedostatci života na selu“ označava viši stupanj percipiranja nedostataka koje donosi život u ruralnim područjima. Iako je metoda glavnih komponenata dala dvije komponente koje su zajedno tumačile 48,0\% ukupne varijance instrumenta, skala zadovoljava Carminesove i Zellerove (1979.) kriterije jednodimenzionalnosti, pa ju kao takvu i tretiramo u daljnjim analizama. Pouzdanost skale izražena Cronbachovim koeficijentom interne konzistentnosti je visoka $(\alpha=0,849)$.

\subsubsection{Skala "Prednosti života na selu“}

Tvrdnje s kojima su se studenti u prosjeku najviše složili na skali „Prednosti života na selu“ su: t4 („Na selu su manje gužve i slobodniji je prostor.“; $\overline{\mathrm{x}}=4,65$ ), s kojom se preko $90 \%$ svih studenata slaže i u potpunosti slaže; t10 („Na selu su bliži kontakti među ljudima, sumještani se poznaju.“; $\overline{\mathrm{x}}=4,30$ ), t01 („Ljudi na selu žive u prirodnom okolišu u užem suživotu s prirodom.“; $\overline{\mathrm{x}}=4,29$ ) te t02 („Selo je manje onečišćeno.“; $\overline{\mathrm{x}}=4,29)$, s kojima se oko $85 \%$ studenata slaže odnosno u potpunosti slaže. Dakle, studenti kao najveće prednosti života u ruralnim područjima vide veću prostornu slobodu i izoliranost, kvalitetne dobrosusjedske odnose te prirodan i čist okoliš.

S druge strane, tvrdnje s kojima se su studenti u prosjeku najmanje složili su: t13 („Na selu nema velikih socijalnih razlika."; $\overline{\mathrm{x}}=2,66)$, s kojom se polovica svih studenata ne slaže odnosno uopće ne slaže, te t11 („Na selu je manje kriminala, alkoholizma, narkomanije i sl."; $\overline{\mathrm{x}}=2,83$ ), s kojom se preko $40 \%$ studenata ne slaže odnosno uopće ne slaže. Ono što je tim česticama zajedničko je to da obje ističu izostanak socijalnih problema i razlika u odnosu na život u gradu, odnosno studenti se u najmanjoj mjeri slažu s time da je život u ruralnim područjima oslobođen svakodnevnih socijalnih problema i devijantnih ponašanja. 
Tablica 2.

Deskripcija čestica skale „Prednosti života na selu“ ( $\mathrm{N}=582 ; \%)$

\begin{tabular}{|c|c|c|c|c|c|c|c|c|}
\hline $\begin{array}{l}\text { Redni } \\
\text { broj } \\
\text { tvrdnje }\end{array}$ & Tvrdnja & 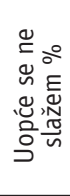 & 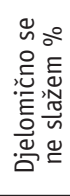 & 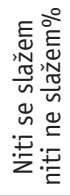 & 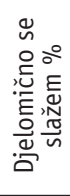 & 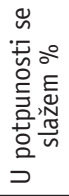 & $\overline{\mathrm{x}}$ & sd \\
\hline 4. & $\begin{array}{l}\text { Na selu su manje gužve i slobodniji } \\
\text { je prostor }\end{array}$ & 0,9 & 2,4 & 2,6 & 19,2 & 74,9 & 4,65 & 0,73 \\
\hline 10. & $\begin{array}{l}\text { Na selu su bliži kontakti među } \\
\text { ljudima, sumještani se poznaju }\end{array}$ & 2,9 & 3,3 & 8,9 & 30,9 & 54,0 & 4,30 & 0,97 \\
\hline 1. & $\begin{array}{l}\text { Ljudi na selu žive u prirodnom okolišu } \\
\text { u užem suživotu s prirodom }\end{array}$ & 1,5 & 6,4 & 5,3 & 34,9 & 51,9 & 4,29 & 0,94 \\
\hline 2. & Selo je manje onečišćeno & 1,9 & 5,0 & 7,4 & 33,8 & 51,9 & 4,29 & 0,94 \\
\hline 6. & Selo čuva tradiciju i običaje & 2,7 & 7,9 & 17,4 & 35,6 & 36,4 & 3,95 & 1,05 \\
\hline 5. & $\begin{array}{l}\text { Prostor za stanovanje na selu je } \\
\text { humaniji }\end{array}$ & 3,8 & 8,8 & 22,3 & 24,2 & 40,9 & 3,90 & 1,15 \\
\hline 3. & Osobna sigurnost ljudi veća je na selu & 4,5 & 8,4 & 20,6 & 34,2 & 32,3 & 3,81 & 1,11 \\
\hline 8. & Na selu je zdravija prehrana & 4,8 & 11,9 & 17,5 & 29,2 & 36,6 & 3,81 & 1,19 \\
\hline 7. & $\begin{array}{l}\text { Ljudi na selu više njeguju vjeru i } \\
\text { vjerski život }\end{array}$ & 5,0 & 9,3 & 27,1 & 30,2 & 28,4 & 3,68 & 1,13 \\
\hline 9. & Na selu su čvršće obiteljske veze & 6,4 & 12,9 & 25,3 & 29,7 & 25,8 & 3,56 & 1,19 \\
\hline 14. & Troškovi života na selu su niži & 11,9 & 16,5 & 26,1 & 27,7 & 17,9 & 3,23 & 1,26 \\
\hline 12. & $\begin{array}{l}\text { Na selu su ljudi izloženi manjem } \\
\text { stresu }\end{array}$ & 10,3 & 18,2 & 26,1 & 29,6 & 15,8 & 3,22 & 1,21 \\
\hline 11. & $\begin{array}{l}\text { Na selu je manje kriminala, } \\
\text { alkoholizma, narkomanije i sl. }\end{array}$ & 16,2 & 25,1 & 27,8 & 21,3 & 9,6 & 2,83 & 1,21 \\
\hline 13. & Na selu nema velikih socijalnih razlika & 17,0 & 33,7 & 23,5 & 17,4 & 8,4 & 2,66 & 1,19 \\
\hline
\end{tabular}

T-test za nezavisne uzorke proveden je za tri klasifikatorske varijable: spol (t1), godina studija (t2) i želja za povratkom/preseljenjem u ruralna područja (t3). Statistički značajna razlika za varijable spola te godine studija nije pronađena $(\mathrm{t} 1=1,05, \mathrm{p}>$ $0,05 ; \mathrm{t} 2=1,11, \mathrm{p}>0,05)$. Stoga zaključujemo da se studenti statistički značajno ne razlikuju po prosječnom rezultatu na skali „Prednosti života na selu“ s obzirom na spol te godinu studija koju trenutno pohađaju. No, za klasifikatorsku varijablu želje za povratkom/preseljenjem u ruralna područja dobivena je statistički značajna razlika (t3 = 5,53, p < 0,01). Dakle, možemo zaključiti kako su studenti koji planiraju nakon završenog studija živjeti u ruralnim područjima skloniji percipirati više prednosti života u njima od onih studenata koji planiraju ostati živjeti u gradu ( $\overline{\mathrm{x}}$ (Imaju namjeru povratka/preseljenja u ruralna područja $)=54,85 ; \bar{x}($ Nemaju namjeru povratka/preseljenja u ruralna područja) $=50,04)$. 
ANOVA test proveden je na četiri klasifikatorske varijable: fakultet (F1), stupanj religioznosti (F2), politička orijentacija (F3) te veličina naselja u kojem su studenti proveli najveći dio života (F4). F-omjer za varijablu fakulteta pokazao se statistički značajan na razini rizika od $1 \%(\mathrm{~F} 1=5,73, \mathrm{p}<0,01)$. Bonferronijev post-hoc test ${ }^{4}$ pokazao je kako su studenti Agronomskog fakulteta skloniji percipirati više prednosti života u ruralnim područjima nego što su to studenti Filozofskog i Prirodoslovno-matematičkog fakulteta $(\overline{\mathrm{x}}$ (Agronomski fakultet $)=56,36 ; \overline{\mathrm{x}}($ Filozofski fakultet $)=50,54$; $\overline{\mathrm{x}}($ Prirodoslovno-matematički fakultet $)=51,30)$.

F-omjer za varijablu stupnja religioznosti također se pokazao statistički značajan na razini rizika od $1 \%(\mathrm{~F} 2=8,49, \mathrm{p}<0,01)$. Tamhaneov T2 post-hoc pokazao je kako su religiozni studenti i oni koji ne mogu procijeniti svoju religioznost skloniji percipirati više prednosti života u ruralnim područjima nego što su to njihove nereligiozne kolege $(\overline{\mathrm{x}}($ Uopće nisam religiozan $/ \mathrm{na})=49,53 ; \overline{\mathrm{x}}(\mathrm{Nisam}$ religiozan $/ \mathrm{na})=50,02 ; \overline{\mathrm{x}}(\mathrm{Niti}$ sam religiozan $/$ na, niti nisam $)=54,11 ; \overline{\mathrm{x}}($ Religiozan $/$ na sam $)=54,41 ; \overline{\mathrm{x}}($ Izrazito sam religiozan $/ \mathrm{na})=54,07)$.

Nadalje, F-omjer za varijablu političke orijentacije pokazao se statistički značajan na razini rizika od $1 \%(\mathrm{~F} 3=10,89, \mathrm{p}<0,01)$. Tamhaneov $\mathrm{T} 2$ post-hoc test pokazao je kako su politički desno orijentirani studenti skloniji percipirati više prednosti života u ruralnim područjima nego što su to studenti orijentirani na političkoj ljevici i centru $(\overline{\mathrm{x}}($ Politički lijevo orijentirani $)=49,65 ; \overline{\mathrm{x}}($ Politički centralno orijentirani $)=50,23$; $\overline{\mathrm{x}}($ Politički desno orijentirani $)=54,91)$.

Posljednji testirani F-omjer za varijablu veličine naselja u kojem su studenti proveli najveći dio života pokazao se statistički značajan na razini rizika od 5\% (F4 = 2,71, p $<0,05)$. Bonferronijev post-hoc test pokazao je kako su studenti koji su većinu života proveli u ruralnim područjima skloniji percipirati više prednosti života u njima nego što su to studenti iz gradova veličine 10.001 do 100.000 stanovnika $(\overline{\mathrm{x}}$ (veličina naselja do 2.000 stanovnika $)=53,48$; $\bar{x}($ Veličina naselja između 10.001 i 100.000 stanovni$\mathrm{ka})=51,47)$.

\subsubsection{Skala "Nedostatci života na selu"}

Tvrdnje s kojima su se studenti u prosjeku najviše složili na skali „Nedostatci života na selu“ su t16 („Na selu su manje mogućnosti za školovanje i profesionalno usavršavanje.“; $\overline{\mathrm{x}}=4,10$ ) i t15 („Selo je siromašnije zabavnim i kulturnim sadržajima.“; $\overline{\mathrm{x}}$ $=3,99)$, s kojima se preko 3/4 studenata slaže odnosno u potpunosti slaže; ali i t17 („Rad na selu teži je i zamorniji, više je fizičkog rada.“; $\bar{x}=3,85$ ), s kojom se preko $2 / 3$

\footnotetext{
${ }^{4}$ Svi post hoc testovi u ANOVA testu provedeni su na razini rizika od $5 \%(p=0,05)$.
} 
studenata slaže odnosno u potpunosti slaže. Dakle, studenti kao najveće nedostatke života u ruralnim područjima vide slabiju mogućnost profesionalnog obrazovanja, nedostatak zabavnih i kulturnih sadržaja te veću težinu rada, naročito fizičkog rada, koji izostaje u gradskom životu.

S druge strane, tvrdnje s kojima su se studenti u prosjeku najmanje složili su t26 („Stambeni prostori na selu lošije su uređeni i slabije opremljeni.“; $\overline{\mathrm{x}}=2,51$ ); t18 („Na selu su manje mogućnosti za ostvarenje gospodarskog uspjeha.“; $\overline{\mathrm{x}}=2,63$ ) te t19 („Seljani imaju manje slobodnog vremena i vremena za odmaranje. “; $\overline{\mathrm{x}}=2,72$ ), s kojima se oko polovice svih studenata ne slaže odnosno uopće ne slaže. Dakle, studenti kao nedostatke života u ruralnim područjima ne vide nižu kvalitetu stambene infrastrukture, smatraju kako je moguće postići gospodarski uspjeh te misle da seljani imaju dovoljno slobodnog vremena za odmor.

Tablica 3.

Deskripcija čestica skale „Nedostatci života na selu“ ( $N=582 ; \%)$

\begin{tabular}{|c|c|c|c|c|c|c|c|c|}
\hline $\begin{array}{l}\text { Redni } \\
\text { broj } \\
\text { tvrdnje }\end{array}$ & Tvrdnja & 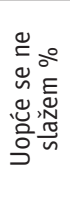 & 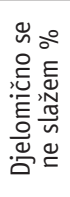 & 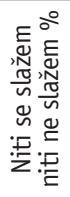 & 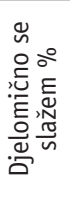 & 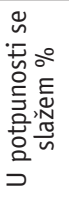 & $\overline{\mathrm{x}}$ & sd \\
\hline 16. & $\begin{array}{l}\text { Na selu su manje mogućnosti za školovanje i } \\
\text { profesionalno usavršavanje }\end{array}$ & 5,5 & 7,4 & 10,5 & 24,6 & 52,1 & 4,10 & 1,19 \\
\hline 15. & $\begin{array}{l}\text { Selo je siromašnije zabavnim i kulturnim } \\
\text { sadržajima }\end{array}$ & 4,8 & 8,9 & 10,7 & 33,5 & 42,1 & 3,99 & 1,15 \\
\hline 17. & $\begin{array}{l}\text { Rad na selu teži je i zamorniji, više je fizičkog } \\
\text { rada }\end{array}$ & 3,6 & 7,4 & 20,8 & 36,6 & 31,6 & 3,85 & 1,06 \\
\hline 25. & Veća je prometna izoliranost sela & 5,5 & 8,8 & 17,5 & 35,2 & 33,0 & 3,81 & 1,15 \\
\hline 20. & Sredina na selu je konzervativnija & 4,3 & 9,3 & 19,8 & 35,4 & 31,3 & 3,80 & 1,11 \\
\hline 22. & $\begin{array}{l}\text { Mogućnost za zapošljavanje visokoobrazovanih } \\
\text { ljudi u mojoj struci na selu su nepostojeće }\end{array}$ & 15,3 & 14,6 & 13,9 & 22,9 & 33,3 & 3,44 & 1,46 \\
\hline 23. & Privatnost pojedinca manja je na selu & 12,5 & 12,9 & 22,2 & 27,8 & 24,6 & 3,39 & 1,32 \\
\hline 21. & Mogućnosti za zaradu na selu su manje & 13,7 & 21,1 & 22,2 & 28,2 & 14,8 & 3,09 & 1,28 \\
\hline 24. & $\begin{array}{l}\text { Komunalna opremljenost (voda, plin i sl.) lošija } \\
\text { je na selu }\end{array}$ & 17,7 & 19,2 & 23,5 & 22,3 & 17,2 & 3,02 & 1,35 \\
\hline 19. & $\begin{array}{l}\text { Seljani imaju manje slobodnog vremena i } \\
\text { vremena za odmaranje }\end{array}$ & 16,2 & 30,2 & 27,3 & 17,7 & 8,6 & 2,72 & 1,18 \\
\hline 18. & $\begin{array}{l}\text { Na selu su manje mogućnosti za ostvarenje } \\
\text { gospodarskog uspjeha }\end{array}$ & 19,8 & 30,1 & 26,1 & 15,5 & 8,6 & 2,63 & 1,21 \\
\hline 26. & $\begin{array}{l}\text { Stambeni prostori na selu lošije su uređeni i } \\
\text { slabije opremljeni }\end{array}$ & 28,0 & 25,1 & 23,5 & 14,6 & 8,8 & 2,51 & 1,28 \\
\hline
\end{tabular}


T-test za nezavisne uzorke i u slučaju je skale „Nedostatci života na selu“ proveden za tri iste klasifikatorske varijable kao i kod skale „Prednosti života na selu“. Statistički značajna razlika za varijable spola te godine studija nije pronađena $(\mathrm{t} 1=-1,27, \mathrm{p}>$ $0,05 ; \mathrm{t} 2=0,98, \mathrm{p}>0,05)$. Stoga zaključujemo da se studenti statistički značajno ne razlikuju po prosječnom rezultatu s obzirom na spol te godinu studija koju trenutno pohađaju. No, za klasifikatorsku varijablu želje za povratkom/preseljenjem u ruralna područja i u ovom je slučaju dobivena statistički značajna razlika $(\mathrm{t} 3=-9,70, \mathrm{p}<$ $0,01)$. Dakle, možemo zaključiti kako su studentice i studenti koji planiraju nakon završenog studija ostati živjeti u gradu skloniji percipirati više nedostataka života u ruralnim područjima od onih studentica i studenata koji planiraju živjeti u ruralnim područjima ( $\bar{x}$ (Imaju namjeru povratka/preseljenja u ruralna područja $)=36,77$; $\overline{\mathrm{x}}($ Nemaju namjeru povratka/preseljenja u ruralna područja $)=44,31)$.

ANOVA test i u ovom je slučaju proveden na istim četirima klasifikatorskim varijablama kao i kod skale „Prednosti života na selu“. F-omjer za varijablu fakulteta pokazao se statistički značajan na razini rizika od $1 \%(\mathrm{~F} 1=7,24, \mathrm{p}<0,01)$. Bonferronijev post-hoc test pokazao je kako su studenti Filozofskog fakulteta skloniji percipirati više nedostataka života u ruralnim područjima za razliku od svojih kolega s Agronomskog fakulteta $(\overline{\mathrm{x}}$ (Agronomski fakultet $)=38,49 ; \overline{\mathrm{x}}($ Filozofski fakultet $)=42,10)$. F-omjer za varijablu stupnja religioznosti također se pokazao statistički značajan na razini rizika od 1\% (F2 = 3,56, $\mathrm{p}<0,01)$. Bonferronijev post-hoc test pokazao je kako su nereligiozni studenti i oni koji ne mogu procijeniti vlastitu religioznost skloniji percipirati više nedostataka života u ruralnim područjima od svojih religioznih kolega $(\overline{\mathrm{x}}$ (Uopće nisam religiozan $/ \mathrm{na})=42,79 ; \overline{\mathrm{x}}($ Religiozan $/ \mathrm{na}$ sam $)=38,95 ; \overline{\mathrm{x}}($ Izrazito sam religio$\mathrm{zan} / \mathrm{na})=36,67)$.

Iako se F-omjer za varijablu političke orijentacije pokazao statistički značajan na razini rizika od 1\% (F3 = 4,27, p < 0,01), Bonferronijev post-hoc test pokazao je kako, na razini rizika od $5 \%$, ne postoje statistički značajne međugrupne razlike.

Posljednji testirani F-omjer za varijablu veličine naselja u kojem su studenti proveli najveći dio života pokazao se statistički značajan na razini rizika od $1 \%$ (F4=9,57, p < $0,01)$. Tamhaneov T2 post-hoc test pokazao je da što je tip naselja u kojem je student proveo većinu života veći, veća je i percepcija nedostataka života u ruralnim područjima. $(\overline{\mathrm{x}}$ (Veličina naselja do 2.000 stanovnika $)=38,43 ; \overline{\mathrm{x}}$ (Veličina naselja između 2.001 i 10.000 stanovnika $)=39,49$; $\overline{\mathrm{x}}$ (Veličina naselja između 10.001 i 100.000 stanovnika) $=41,26 ; \overline{\mathrm{x}}($ Veličina naselja preko 100.000 stanovnika $)=43,55)$. 


\section{Zaključak}

Revitalizacija hrvatskih ruralnih područja moguća je samo ako se mlade naraštaje potakne na ostanak odnosno povratak u njih. Da bi se to ostvarilo, potrebno je ispitati koji čimbenici utječu na odluku mladih o ostanku ili povratku/preseljenju. U ovom radu fokusirali smo se na visokoobrazovano mlado stanovništvo jer je nastavak obrazovanja često prvi korak ka trajnom odlasku mladih iz ruralnih područja. Visoko obrazovanje odvija se u većim gradovima i zbog toga su mladi primorani na privremeno napuštanje svojih rodnih mjesta i preseljenje. Nakon nekoliko godina obrazovanja i života u gradu mladi se ljudi teško odlučuju na povratak i često trajno nastavljaju svoj život u gradovima. Međutim, ta je populacija od iznimne važnosti jer njihovo visoko obrazovanje predstavlja važan kapital razvoja ruralnih područja.

Rezultati istraživanja pokazali su da $40 \%$ studenata u našem uzorku trenutno ima želju za životom u ruralnim područjima. Kao prednosti života u ruralnim područjima studenti se u najvećem postotku slažu s tim da je manja gužva i da je prostor za stanovanje humaniji nego u gradu, da je prednost prirodan okoliš, manje onečišćenja te da su kontakti među ljudima bliži. Nedostaci života u ruralnim područjima s kojima se studenti u najvećem postotku slažu uključuju manje mogućnosti za školovanje i profesionalno usavršavanje, teži rad, nedostatak zabavnih i kulturnih sadržaja te veću prometnu izoliranost. Dio istraživanja koje se bavilo infrastrukturnom opremljenošću pokazalo je da studenti koji žele živjeti u ruralnim područjima zahtijevaju da je komunalna infrastruktura u dobrom stanju, prije svega da ruralno naselje u kojem bi živjeli ima struju, vodovod, kanalizaciju, internet i odvoz smeća. Istraživanje je pokazalo i da je studentima iznimno važna prometna infrastruktura i dobra cestovna povezanost $s$ gradom. Dobra povezanost $s$ gradom utječe na smanjenje potrebe stanovnika ruralnih područja za drugim financijskim, zdravstvenim i kulturnim sadržajima u samom ruralnom naselju, a ujedno smanjuje i važnost postojanja radnog mjesta u mjestu stanovanja. Ti su rezultati u skladu s postojećim domaćim istraživanjima, u kojima ruralni mladi ukazuju na probleme vezane za otežan pristup edukaciji, zapošljavanju te teže uvjete rada, posebice u poljoprivredi (Žutinić i sur., 2010.:152; Žutinić i Bokan, 2008.:150; Šundalić, 2006.:141; Stipić, 2018.:20, 35). Istovremeno, odgovaraju i dominantnoj temi problema s infrastrukturnom neopremljenošću, na što su već upozoravali ruralni mladi, posebno vezano za lošu prometnu infrastrukturu i povezanost s obližnjim naseljima te pristup socijalnim i kulturnim sadržajima (Žutinić i Bokan, 2008.:151; Šundalić, 2006.:141; Babić i Lajić, 2001.:79; Grgić i sur., 2010.:600; Pupak, 2020.:40).

S obzirom na naše hipoteze, prva hipoteza $(\mathrm{H} 1)$, kojom smo pretpostavili da će većina visokoobrazovanih mladih iz grada značajno više percipirati nedostatke života u ruralnim područjima i htjeti ostati u gradu u odnosu na mlade iz ruralnih područja, koji će značajno više percipirati prednosti života u ruralnim područjima i htjeti se vratiti nakon završetka studija, je potvrđena. Druga hipoteza (H2), kojom smo pretpostavili 
da će žene, studenti prve godine studija, studenti Agronomskog i Šumarskog fakulteta, religiozniji studenti i politički desno orijentirani studenti značajno više percipirati prednosti života u ruralnim područjima i htjeti se vratiti nakon završetka studija u odnosu na muškarce, studente zadnje (pete) godine studija, studente ostalih fakulteta, nereligiozne i politički lijevo orijentirane, samo je djelomično potvrđena. Naime, pokazalo se da su muškarci, a ne žene, skloniji životu u ruralnim područjima, dok t-testom nismo dobili statistički značajne razlike u percepciji prednosti i nedostataka između te dvije grupe. Također, suprotno našoj pretpostavci, pokazalo se da su studenti zadnje (pete) godine, a ne studenti prve godine studija, skloniji životu u ruralnim područjima, dok t-testom nismo dobili statistički značajne razlike u percepciji prednosti i nedostataka između te dvije grupe. S druge strane, kao što smo i pretpostavili, studenti Agronomskog i Šumarskog fakulteta najviše su skloni povratku/preseljenju u ruralna područja, a studenti Agronomskog fakulteta ujedno i percipiraju najviše prednosti života u ruralnim područjima. U skladu s našom pretpostavkom, religiozniji studenti skloniji su povratku/preseljenju u ruralna područja, dok su nereligiozni studenti skloniji ostanku u gradu, a religiozniji studenti ujedno i značajnije više percipiranju prednosti života u ruralnim područjima. Nadalje, kao što smo i pretpostavili, studenti desne političke orijentacije najskloniji su povratku/preseljenju u ruralna područja nakon završenog studija, dok su studenti lijeve političke orijentacije skloniji ostanku u gradu, a politički desno orijentirani studenti ujedno i značajnije više percipiranju prednosti života u ruralnim područjima.

Prema odgovorima studenata u ovom istraživanju, ključ revitalizacije ruralnih područja, odnosno povećanja njihove privlačnosti za život, posebice mlade visokoobrazovane populacije, leži prije svega u boljoj komunalnoj i prometnoj infrastrukturi. Mladi visokoobrazovani studenti u najvećoj mjeri ne mogu tražiti zaposlenje u ruralnim naseljima, pa da bi se odlučili na život u ruralnim područjima zahtijevaju dobru prometnu povezanost s gradovima u kojima planiraju raditi. Više od $70 \%$ onih koji ne žele živjeti u ruralnim područjima naveli su da su mogućnosti za zapošljavanje visokoobrazovanih ljudi u njihovoj struci tamo nepostojeće. Rješavanje problema deagrarizacije vide u novčanim poticajima za mlade poljoprivrednike, koje važnima smatra čak 53\% studenata koji su podrijetlom iz ruralnih područja i 40\% studenata koji su podrijetlom iz grada. Uz pomoć takvih poticaja mladima se olakšava početak bavljenja poljoprivredom. To je u skladu is drugim istraživanjima ruralnih mladih, u kojima se ističe važnost financijske potpore (Pupak, 2020.: 34-35; Stipić, 2018.:28). Smatramo da bi takvi poticaji mogli biti od posebne važnosti za one koji su podrijetlom iz grada, a željeli bi se baviti poljoprivredom, s obzirom na to da oni u većini slučajeva nemaju zemljišta ni strojeva koje mladi iz ruralnih područja najčešće obiteljski nasljeđuju, pa bi im novčana potpora olakšala početak bavljenja poljoprivredom.

Ograničenja ovog istraživanja leže u prigodnosti uzorka te internetskoj provedbi ankete, što nam ne dopušta zaključivanje o cjelokupnoj studentskoj populaciji. Preporuka 
je svakako za buduća sveobuhvatnija istraživanja da ispitaju na koji bi se način mlade moglo odvratiti od toga da nakon studija ostaju u gradovima. Osim toga, bilo bi dobro napraviti distinkciju prema regijama u Hrvatskoj jer zbog velikih regionalnih razlika smatramo da bi se razlozi odlaska mladih iz ruralnih područja mogli razlikovati od regije do regije. Međutim, posebice zbog malog broja socioloških istraživanja koja se bave ovom temom, smatramo ove rezultate važnima kao svojevrsni doprinos produbljivanju razumijevanja problematike odlaska i nepovratka visokoobrazovanih mladih ljudi u hrvatska ruralna područja. Problematika mladih u ruralnim područjima danas je jedna od najvažnijih tema europskih strategija i politika ruralnog razvoja, te smatramo ova i slična istraživanja nužnima kao podlogu u sastavljanju domaćih razvojnih strategija prilagođenih specifičnostima hrvatskog sociodemografskog konteksta.

\section{Literatura}

1. Babić, D. i Lajić, I. (2001). Dilema mladih otočana: ostanak ili odlazak s otoka. Primjer šibenskih otoka. Sociologija sela, 39 (1/4; 151/154): 61-82.

2. Bednarikova, Z.; Bavorova, M. and Ponkina, E. (2016). Migration Motivation of Agriculturally Educated Rural Youth: The Case of Russian Siberia. Journal of Rural Studies, 45: 99-111.

3. Carmines, E. G. and Zeller, R. A. (1979). Reliability and Validity Assessment. Sage Publications.

4. Cifrić I. (2013). Dimenzije sociokulturnog identiteta, u: Cifrić, I.; Trako Poljak T. i Klasnić K. (Ur.). Hrvatski identitet u promjeni? Relacijski identiteti 2. Zagreb: Biblioteka „Razvoj i okoliš“: 23-62.

5. Cifrić, I. (2018). Selo i seljaci - glavna obilježja i točke promjena, u: Batina, K.; Fakin Bajec, J.; Petrović Leš, T.; Poljak Istenič, S. (Ur.). Etnologija i selo 21. stoljeća: tradicionalno, ugroženo, kreativno 14. hrvatsko-slovenske etnološke paralele. Hrvatsko etnološko društvo i Hrvatsko slovensko društvo: 5-15.

6. DZS - Državni zavod za statistiku (2001). https://www.dzs.hr/hrv/censuses/ census2011/results/htm/H02 05/H02 05.html. (Pregledano 30. srpnja 2021.)

7. DZS - Državni zavod za statistiku (2011). https://www.dzs.hr/hrv/censuses/ census2011/censuslogo.html. (Pregledano 27. lipnja 2019.)

8. E-usmjeravanje (2020). http://www.e-usmjeravanje.hzz.hr/obrazovanje. (Pregledano 22. kolovoza 2020.)

9. Grgić, I.; Žimbrek, T.; Tratnik, M.; Markovina, J.; Juračak, J. (2010). Quality of Life in Rural Areas of Croatia: To Stay or to Leave? African Journal of Agricultural Research, 5 (8): 653-660.

10. Hodžić, A. (2006). Selo kao izbor. Zagreb: Institut za društvena istraživanja u Zagrebu.

11. Horváth, I. (2008). The Culture of Migration of Rural Romanian Youth. Journal of Ethnic and Migration Studies, 34 (5): 771-786. 
12. Ministarstvo poljoprivrede (2018). Program ruralnog razvoja Republike Hrvatske za razdoblje 2014.-2020. https://ruralnirazvoj.hr/files/documents/Programruralnog-razvoja-Republike-Hrvatske-za-razdoblje-2014.-2020.-ver.-5.3.pdf. (Pregledano 30. srpnja 2021.)

13. MOZVAG-preglednik studijskih programa (2020). http://www.mozvag.srce. hr/preglednik/pregled/hr/podrucje/prikaziPolje.html?oznakapodrucje=4\&ozna kapolje=4.01. (Pregledano 22. kolovoza 2020.)

14. Nejašmić, I. (1990). Osnovne značajke depopulacije u Hrvatskoj u razdoblju 1953-1981. Sociologija i prostor, (107-108): 33-50.

15. Petak, A. (2002). Śto znamo o mladim seljacima?, u: Okrugli stol Selo u tranziciji, Institut za društvena istraživanja u Zagrebu, 19. travnja 2001. godine. Sociologija i prostor, 40 (1/2; 155/156): 43-48.

16. Petak, A.; Puljiz, V. i Štambuk, M. (2002). Časopis Sociologija sela, razvoj sela i poljoprivrede, razvoj ruralne sociologije. Sociologija i prostor, 40 (3-4; 157-158): 227-251.

17. Puljiz, V. (2002). Oblici i posljedice deagrarizacije u našem selu. Sociologija $i$ prostor, 40 (3/4; 157/158): 367-385.

18. Pupak, H. (2020). Iskustva mladih obiteljskih poljoprivrednih gospodarstvenika (OPG-ovaca) u Bjelovarsko-bilogorskoj i Požeško-slavonskoj županiji. Diplomski rad. Zagreb: Filozofski fakultet, Sveučilište u Zagrebu. https://urn.nsk.hr/ urn:nbn:hr:131:367418. (Pregledano 30. srpnja 2021.)

19. Seferagić, D. (2002). Selo između tradicionalne i virtualne zajednice, u: Seferagić, D.; Župančić, M.; Hodžić, A.; Svirčić, A.; Milinković, B. (Ur.). Selo: izbor ili usud. Zagreb: Institut za društvena istraživanja u Zagrebu: 11-33.

20. Stipić, S. (2018). Stavovi i mišljenja mladih o prednostima i nedostacima življenja na selu. Diplomski rad. Zagreb: Sveučilište u Zagrebu, Agronomski fakultet. https://urn.nsk.hr/urn:nbn:hr:204:246624. (Pregledano 30. srpnja 2021.)

21. Stockdale, A. (2006). Migration: Pre-Requisite for Rural Economic Regeneration? Journal of Rural Studies, 22 (3): 354-366.

22. Svirčić Gotovac, A. (2006). Kvaliteta stanovanja u mreži naselja Hrvatske. Sociologija i prostor, 44 (171; 1): 105-126.

23. Štambuk, M. (2014). Razvojna samoodrživost na ruralnom teritoriju, u: Štambuk, M. i Šikić-Mićanović, L. (Ur.). Ruralna općina: sutra. Društvena rel konstrukcija na ruralnom teritoriju. Zagreb: Institut društvenih znanosti „Ivo Pilar": 9-23.

24. Štambuk, M. i Mišetić, A. (2002). Neki elementi socijalne i tehničke infrastrukture hrvatskog sela, u: Štambuk M.; Rogić, I. i Mišetić A. (Ur.). Prostor iza: kako modernizacija mijenja hrvatsko selo. Zagreb: Institut društvenih znanosti Ivo Pilar: 155-176.

25. Šuljok, A. (2006). Socijalno podrijetlo mladih znanstvenika i (samo)obnavljanje znanosti. Sociologija i prostor, 44 (172/173; 2/3): 289-308.

26. Šundalić, A. (2006). Osiromašivanje i nerazvijenost - Slavonija i Baranja u očima njezinih stanovnika. Socijalna ekologija, 15 (1-2): 125-143. 
27. Šundalić, A. (2010). Selo - iz autentičnosti u neprepoznatlivivost. Osijek: Sveučilište J. J. Strossmayera u Osijeku.

28. Thissen, F.; Fortuijn, J.; Strijker, D.; Haartsen, T. (2010). Migration Intentions of Rural Youth in the Westhoek, Flanders, Belgium and the Veenkoloniën, The Netherlands. Journal of Rural Studies, 26: 428-436.

29. Župančić, M. (2000). Tranzicija i modernizacijske perspektive hrvatskog sela. Sociologija i prostor, (147-148): 11-78.

30. Župančić, M. (2005). Infrastrukturna opremljenost hrvatskih seoskih naselja. Sociologija i prostor, 43 (3; 169): 617-657.

31. Žutinić, Đ. and Bokan, N. (2008). Village - Free Choice or Destiny for the Rural Youth (A Study on the Rural Community of Vodinci). Sociologija i prostor, 46 (2; 180): 143-160.

32. Žutinić, Đ.; Kovačić, D.; Grgić, I.; Markovina, J. (2010). Percepcija kvalitete življenja i namjere o odlasku iz ruralnih sredina. Društvena istraživanja, 19 (1-2; 105-106): 137-159. 


\title{
Pros and Cons of Rural Living. Attitudes of Highly Educated Young People About Living in Croatian Rural Areas
}

\author{
Tihana Kuzmić \\ University of Zargreb, Faculty of Humanities and Social Sciences, Department of Sociology, Croatia \\ e-mail: kuz.tih@gmail.com \\ Bruno šimac \\ University of Zargreb, Faculty of Humanities and Social Sciences, Department of Sociology, Croatia \\ e-mail: bsimac@ffzg.hr
}

Tijana Trako Poljak

University of Zargreb, Faculty of Humanities and Social Sciences, Department of Sociology, Croatia e-mail: ttrako@ffzg.hr

\begin{abstract}
The exodus of young people represents one of the key issues for the survival of Croatian rural areas in the demographic sense, but also, consequentially, in the economic, social, cultural, political and every other aspect. The decrease in the number of young people among the rural population is visible in the senilization of the rural areas, as well as deagrarization, and overall deruralization, and a continued decline of rural areas as places of life and work. Considering that the young population is mostly leaving the rural areas because of education and employment, especially in sectors that employ the higher educated, the aim of this article is to examine the push and pull factors for returning or moving to the rural areas from the perspective of the Croatian young higher educated population.
\end{abstract}

This article brings the results from the quantitative empirical study conducted in 2020 using the method of online questionnaire on the convenient sample of $\mathrm{N}=582$ students from six faculties of the University of Zagreb, which encompassed all major scientific and art fields. The students were asked about their perception of the advantages and disadvantages of living in rural areas, as well as about their desire for moving or returning to the rural areas after finishing their education, and the reasons why. They were also asked about specific elements of infrastructure that were shown in previous research as an important factor in their decision to return or move to rural areas. Finally, the responses were correlated with their socio-demographic characteristics.

The results show that $40 \%$ of students want to return/move to rural areas, with over half of students (55\%) who come from rural areas, and significantly less those from urban areas, who prefer to stay in the cities. In order to attract the higher educated young population to rural areas, the key is to improve communal and traffic infrastructure, as well as provide more opportunities for them to work in their professions, primarily by enabling better traffic connection with neighbouring cities in which they plan to work. Regarding work in agriculture, they feel that financial support, especially for urban young people who do not have family farms and existing infrastructure to rely on, would make their beginnings in agriculture easier.

Key words: rural exodus, deagrarization, higher educated young population, Croatian rural areas, rural development. 